\title{
17: 60985289-60956106
}

National Cancer Institute

\section{Source}

National Cancer Institute. 17: 60985289-60956106. NCI Thesaurus. Code C41735.

Physical location of AXIN2_Gene 